University of Nebraska - Lincoln

DigitalCommons@University of Nebraska - Lincoln

2012

\title{
Regulation of Water Pollution from Hydraulic Fracturing in Horizontally-Drilled Wells in the Marcellus Shale Region, USA
}

Heather Hatzenbuhler

University of Georgia, heatherhatz@gmail.com

Terence J. Centner

University of Georgia, tcentner2@unl.edu

Follow this and additional works at: https://digitalcommons.unl.edu/ageconfacpub

Hatzenbuhler, Heather and Centner, Terence J., "Regulation of Water Pollution from Hydraulic Fracturing in Horizontally-Drilled Wells in the Marcellus Shale Region, USA" (2012). Faculty Publications: Agricultural Economics. 182.

https://digitalcommons.unl.edu/ageconfacpub/182

This Article is brought to you for free and open access by the Agricultural Economics Department at DigitalCommons@University of Nebraska - Lincoln. It has been accepted for inclusion in Faculty Publications: Agricultural Economics by an authorized administrator of DigitalCommons@University of Nebraska - Lincoln. 
Article

\title{
Regulation of Water Pollution from Hydraulic Fracturing in Horizontally-Drilled Wells in the Marcellus Shale Region, USA
}

\author{
Heather Hatzenbuhler and Terence J. Centner* \\ Department of Agricultural and Applied Economics, College of Agricultural and Environmental \\ Sciences, The University of Georgia, Athens, GA 30602, USA; E-Mail: heatherhatz@gmail.com \\ * Author to whom correspondence should be addressed; E-Mail: tcentner@uga.edu; \\ Tel.: +1-706-542-0756; Fax: +1-706-542-0339.
}

Received: 9 October 2012; in revised form: 16 November 2012 / Accepted: 22 November 2012 / Published: 4 December 2012

\begin{abstract}
Hydraulic fracturing is an industrial process used to extract fossil fuel reserves that lie deep underground. With the introduction of horizontal drilling, new commercial sources of energy have become available. Wells are drilled and injected with large quantities of water mixed with specially selected chemicals at high pressures that allow petroleum reserves to flow to the surface. While the increased economic activities and the outputs of domestic energy are welcomed, there is growing concern over negative environmental impacts from horizontal drilling in shale formations. The potential for water contamination, land destruction, air pollution, and geologic disruption has raised concerns about the merits of production activities used during extraction. This paper looks at the impacts of horizontal drilling using hydraulic fracturing on water supplies and takes a comprehensive look at legislative and regulatory approaches to mitigate environmental risks in the Marcellus shale region. The overview identifies shortcomings associated with regulatory controls by local and state governments and offers two policy suggestions to better protect waters of the region.
\end{abstract}

Keywords: horizontal drilling; hydraulic fracturing; water pollution; governmental regulation

\section{Introduction}

In the last four years, horizontal drilling using many fractures along a horizontal wellbore has been used commercially to access the deepest shale gas (over $1800 \mathrm{~m}$ below the surface) in the United States [1,2]. Horizontal drilling employs turning a downward-plodding drill bit to continue drilling within 
a layer underneath the ground. Accompanying horizontal drilling is hydraulic fracturing, a well-stimulation technique that maximizes extraction of oil and natural gas in unconventional reservoirs such as shale, coalbeds and tight sands. Hydraulic fracturing involves injecting specially engineered fluids consisting of chemicals and granular material into the wells at incredible pressure to break up the fuel stores and stimulate the flow of natural gas or oil to the surface [1]. Once the well has been fractured, the pressure forces out some of the injection fluids containing chemicals, brines, metals, radionuclides and hydrocarbons [3]. For some wells, the toxic flowback fluids are removed and later injected into class II injection wells [4]. In other situations, the fluids are recycled or are transported to local wastewater treatment facilities. As a result of horizontal drilling, there has been a significant increase in the natural gas supply and a reduction in wholesale spot price of natural gas by nearly $50 \%$ [5].

The risks associated with all aspects of fracturing have been looked at from a variety of perspectives, but most concerns revolve around the use of water resources and their potential contamination [6]. Other risks are associated with surface spills [7,8]. The United States Environmental Protection Agency (EPA) has been investigating drinking water contamination and is expected to complete an extensive study on all aspects of hydraulic fracturing in 2014 [9]. A conclusion that may be drawn from a review of recent scientific studies and incidences is that horizontal drilling accompanied by hydraulic fracturing poses threats to local environmental conditions and the health and safety of persons using land, water, and air resources.

\section{Federal and Regional Policies}

Several federal and regional policies have been adopted to oversee potential risks related to hydraulic fracturing. However, amendments to the federal laws have limited the federal government's oversight of activities accompanying the development of shale gas resources. An overview of relevant legislation, summarized in Table 1, enumerates the role EPA and other agencies could play in minimizing negative impacts of natural gas production.

Table 1. Summary of federal and regional legislation.

\begin{tabular}{|c|c|c|}
\hline Legislation & Authority/Jurisdiction & Potential oversight for hydraulic fracturing \\
\hline CERCLA-1980 & $\begin{array}{l}\text { None currently*/Clean-up } \\
\text { of hazardous waste sites }\end{array}$ & $\begin{array}{l}\text { Might hold companies responsible for clean-up and damages } \\
\text { due to releases of hazardous materials at well sites and require } \\
\text { reporting of toxic chemicals used in the fracturing process. }\end{array}$ \\
\hline CWA-1972 & $\begin{array}{l}\text { EPA/Waters of the United } \\
\text { States }\end{array}$ & $\begin{array}{l}\text { NPDES stormwater permit required for discharges from well } \\
\text { sites but could be extended to apply to temporary holding pits. }\end{array}$ \\
\hline RCRA-1976 & $\begin{array}{l}\text { None currently*/Hazardous } \\
\text { wastes }\end{array}$ & $\begin{array}{l}\text { Could require the listing of hazardous substances used in the } \\
\text { injection fluids in addition to regulation of the resulting } \\
\text { wastewater flowback. }\end{array}$ \\
\hline $\begin{array}{l}\text { SDWA-2005 } \\
\text { amendment }\end{array}$ & $\begin{array}{l}\text { None currently*/Drinking } \\
\text { water of the United States }\end{array}$ & $\begin{array}{l}\text { The UIC program could regulate subsurface emplacement fluids } \\
\text { that would include injection for gas development and underground } \\
\text { storage of waste fluids. }\end{array}$ \\
\hline $\begin{array}{l}\text { SRBC-1971 and } \\
\text { DRBC-1961 }\end{array}$ & $\begin{array}{l}\text { Commissioners/Susquehanna } \\
\text { and Delaware River Basins }\end{array}$ & $\begin{array}{l}\text { Regulates deposits or withdrawals from the river basin so that } \\
\text { fracturing operations need permits to withdraw water for injecting } \\
\text { into wells or for depositing wastewaters back into the river system. }\end{array}$ \\
\hline
\end{tabular}

Note: * Exemptions exist that prohibit EPA from applying these standards to oil and gas extraction. 
In 1972, the Clean Water Act (CWA) delineated the basic structure for regulating discharges of pollutants into waters and for establishing quality standards for surface waters under the authority of EPA [10]. Under the CWA's National Pollutant Discharge Elimination System program, stormwater permits were required for sediment runoff from construction sites and discharges of pollutants into surface waters [11]. The permitting system requires adoption of technology-based and water quality-based effluent limits $[11,12]$. Fracturing activities that inject liquid into the ground or store waters in temporary pits without any discharge are not regulated under the CWA. Thus, there is no federal oversight of fracturing activities until there is proof of fracturing contaminants in surface waters [13].

Congress acted to protect drinking water in the Safe Drinking Water Act of 1976 with protection through the implementation of an Underground Injection Control program regulating subsurface injections and storage of fluids. But, in the Energy Policy Act of 2005, Congress enacted an exclusion to this program.

The term "underground injection"-(A) means the subsurface emplacement of fluids by well injection; and (B) excludes - (i) the underground injection of natural gas for purposes of storage; and (ii) the underground injection of fluids or propping agents (other than diesel fuels) pursuant to hydraulic fracturing operations related to oil, gas, or geothermal production activities [14].

While the Safe Drinking Water Act specifically excludes hydraulic fracturing from regulation, the use of diesel fuel in fracturing is regulated since it is defined as a hazardous contaminant [14].

Congress regulated hazardous waste from inception to disposal under the Resource Conservation and Recovery Act (RCRA) and EPA has developed a list of regulated substances [15]. However, RCRA does not regulate hazardous wastes involved in oil and gas extraction and production under RCRA Subtitle C. These materials are subject to state regulation under the less stringent RCRA Subtitle D solid waste regulations as well as other federal regulations, although states are also free to adopt more demanding provisions. In a publication regarding the exemption EPA says, "Although they are relieved from regulation as hazardous wastes, the exemption does not mean these wastes could not present a hazard to human health and the environment if improperly managed" [16]. The absence of any federal requirement to disclosure hazardous chemicals used in fracturing is a major issue [17].

Hydraulic fracturing, like any deep drilling operation, is subject to the risk of leaks and spills that can cause areas to be contaminated by hazardous waste. In 1980, the Comprehensive Environmental Response, Compensation, and Liability Act (CERCLA) provided for the clean-up of abandoned hazardous waste and established liability to those who released the wastes to pay for clean-up [18]. Yet oil and gas exploration is exempt from clean-up of accidental spills, leaks, and problems from underground injection via the Energy Policy Act of 2005 [19]. Exploration and production companies cannot be held liable for damages under CERCLA, nor may they be sued by any entity for replacement of drinking water supplies or any health problems created as a result of their operations [20].

Applicable to fracturing regulation are two regional commissions that have jurisdiction over all water withdrawals from specific watersheds: the Delaware River Basin Commission and the Susquehanna River Basin Commission. Figure 1 illustrates the overlap of the Marcellus shale formation and several river basins. Because of regulations adopted by these commissions, all oil and gas production operations must obtain permits before they can pump millions of gallons of water to use in their wells. Therefore, 
these commissions play a critical role in the continuation of oil and gas development in the Marcellus shale region because hydraulic fracturing cannot occur without significant quantities of water.

Figure 1. Map of the Marcellus shale assessment units (AU) which are located within the Appalachian Basin Province.

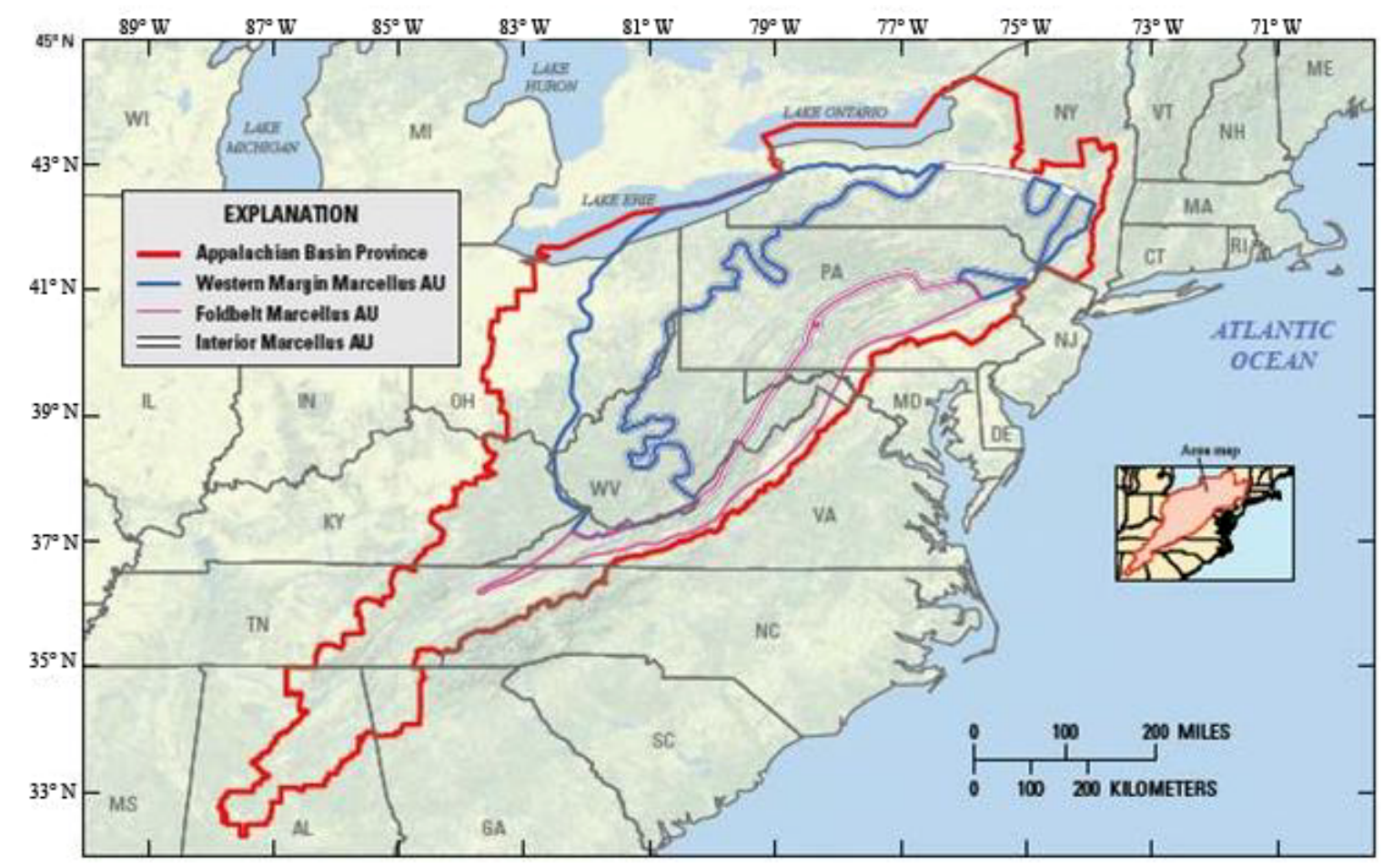

The Delaware River Basin Commission is a regulatory body that was established in 1961 by a congressional compact. It includes a division engineer from the US Army Corps of Engineers and representatives from New York, Pennsylvania, New Jersey, and Delaware who are appointed individually by the executive office in each state [21]. Any decision of the Commission involves the approval of all members. The Commission has full water resource management authority, including water allocations and diversions. Any project that will withdraw or discharge water in or from the basin must be approved by a process that includes a public hearing. In 2009, the Delaware River Basin Commission banned new exploration and production of shale gas in the region until strong regulations are in place. Public comments on draft regulations for natural gas well pad projects were closed in April 2011, and they are currently being reviewed by the commission [22].

Similarly, the Susquehanna River Basin Compact established the Susquehanna River Basin Commission, another federal-interstate regulatory collaboration by Congress and the member states. It is parallel in structure and authority to the Delaware River Basin Commission. Any decision of the Commission involves the approval of all of the member parties, which include the states of Maryland, Pennsylvania, and New York, as well as the federal government. The Susquehanna River is in the Marcellus shale region so any hydraulic fracturing operation using surface waters will need a permit (see Figure 1). At the 15 March 2012 commission meeting, several natural gas drilling projects were rejected and many more reconsidered or tabled [23].

Due to exceptions to federal environmental laws detailed above, the federal government does not have a clear role to play in the regulation of hydraulic fracturing as a result of amendments made to the 
environmental laws detailed above. The exceptions have allowed for more liberal oil and gas development in areas not within the Delaware and Susquehanna river basins. However, EPA has announced that new federal standards for fracturing wastewater are being developed [24]. Even if these are implemented, the regulatory authority to address potential risks has been passed down to the states. States in the region have a range of different approaches to address environmental concerns that accompany horizontal drilling.

\section{State Policies and Actions}

Five states in the Marcellus Shale region, New York, Pennsylvania, Ohio, West Virginia, and Virginia (Figure 1), have different approaches to regulating oil and gas development involving horizontal drilling. These distinct regulatory structures, as well as the significant policy changes made by states in the last two years, illustrate a spectrum of possibilities and outcomes. These structures and outcomes can be used to guide future policy alternatives and decisions. A summary of the current policies and incidences can be found in Table 2 .

Table 2. Summary of state regulations and outcomes.

\begin{tabular}{llll}
\hline State & Regulatory Authority & Legislative Actions & Reported Incidents \\
\hline New York & Department of & $\bullet$ statewide moratorium & $\bullet$ well water contamination \\
& Environmental Protection & $\bullet$ SPDES permit & from vertical wells \\
& & $\bullet$ disclosure of fracturing fluids & \\
& & $\bullet$ municipal zoning bans & \\
\hline Ohio & Department of Natural & $\bullet$ restrictions for impoundment pits & $\bullet$ earthquakes \\
& Resources & $\bullet$ fees for wastewater disposal & $\bullet$ well and surface water \\
& & $\bullet$ electronic tracking & contamination \\
\hline Pennsylvania & Department of & $\bullet$ Act 13 of 2012 set stricter standards & $\bullet$ local water supply \\
& Environmental Protection & for oil and gas production and & contamination \\
& & preempted most municipal regulations & \\
\hline Virginia & Department of Mines & $\bullet$ the Gas and Oil Act allows the & $\bullet$ noxious fumes \\
& Minerals and Energy & non-disclosure of chemicals and & $\bullet$ light pollution \\
& & preempts municipal regulations & $\bullet$ well and surface water \\
& & & contamination \\
& & & $\bullet$ disruption from truck \\
& & & traffic \\
\hline West Virginia & Department of & $\bullet$ the Horizontal Well Act of 2011 & $\bullet$ drinking water \\
& Environmental Protection & preempted municipal regulations and & contamination and \\
& & exempts activities & neurological disease \\
& & & $\bullet$ creek contamination with \\
& & & a massive fish kill \\
\hline
\end{tabular}

New York placed a moratorium on hydraulic fracturing in 2008 [25], and subsequently an executive order directed the state Department of Environmental Conservation to conduct a review and analysis of horizontal hydraulic fracturing [26]. The state has allowed hydraulic fracturing [27]; its horizontal hydraulic fracturing that is precluded. The state has developed a complex and comprehensive regulatory framework [28]. New York is also unique due to the local court battles between citizens and oil and 
gas companies concerning bans on hydraulic fracturing. Since 2008, 22 cities have rezoned to prohibit fracturing [29]. The city of Dryden is one of these local governments that banned horizontal hydraulic fracturing via a zoning law [30]. A natural gas production company filed suit against the city claiming that the municipality was overstepping its jurisdiction. In early 2012, a state superior judge ruled that the municipality was not preempted by state laws and had the right to tighten its land use regulations. Zoning bans by local governments across New York send a strong message about local disapproval of hydraulic fracturing and have established a precedent for other municipalities to limit the drilling rights of oil and gas companies. In New York, either a State Pollution Discharge Elimination System (SPDES) individual or general permit is required for fracturing activities that cause a discharge into surface waters [31]. For high-volume hydraulic fracturing activities, a special general permit has been proposed [32]. The special general permit addresses drilling operations from the construction phase through to the production phase, including well-site construction, soil disturbance, and potential contamination [32]. Hydraulic fracturing would be precluded in the New York City and Syracuse watersheds, on certain state lands, within $610 \mathrm{~m}$ of public drinking water supplies, and within $152 \mathrm{~m}$ of private wells. Furthermore, provisions require the identification and evaluation of fracturing fluid additives "to encourage the use of processes and substances that minimize the potential for environmental impacts" [32].

In Ohio, public concern about hydraulic fracturing came to a head on New Year's Eve 2011 when there was a 4.0 earthquake near the city of Youngstown. This seismic event followed several other earthquakes that began in March 2011, just three months after a $2804 \mathrm{~m}$ wastewater well was drilled in Youngstown for the storage of fracturing fluids. There is no record of seismic activity in this area during the previous 235 years [33]. Rather, the exponential growth in natural gas and storage well drilling in the area, jumping from an average of four new permanent-waste storage wells per year from 1990-2010 to 29 new wells in 2011, seems to have caused the seismic activity. Experts at the Ohio Department of Natural Resources concluded that the seismic disruptions were a result of brine injection related to hydraulic fracturing. Other research supports these claims, as it is widely understood that injecting fluid underground at high pressure can trigger earthquakes [34]. Any geologic disruption in an area where hazardous waste is permanently stored might result in contamination of ground and surface waters. In the last two years, Ohio has implemented further restrictions on impoundment pits located in urban areas, fees for disposal of wastewater via injections in wells, requirements for more comprehensive geologic data prior to permitting, and electronic tracking systems to identify the makeup of drilling wastewater fluids $[35,36]$. The Ohio Department of Natural Resources has regulatory authority over hydraulic fracturing activities in the state.

In Pennsylvania, the Department of Environmental Protection has authority over hydraulic fracturing activities. In 2012, the state legislature passed Act 13 containing stronger and more detailed regulations including increased setback requirements for unconventional gas development, enhanced protection of water supplies, and strong, uniform, consistent statewide environmental standards [37]. This legislation included a uniformity provision that attempted to preempt "all local ordinances regulating oil and gas operations" [38]; however, a Pennsylvania court found this provision to be unconstitutional [39].

The legislature of Virginia decided to encourage the economical extraction of Virginia's coalbed methane [40]. Through the Gas and Oil Act, the state legislature preempted local regulations to give 
the Virginia Department of Mines, Minerals, and Energy the exclusive authority to regulate activities relating to oil and gas exploration and production [41]. The act establishes regulations and permitting requirements that govern mineral extraction. The act does not require the reporting of the chemical composition of fracturing fluids.

In West Virginia, a number of environmental problems have allegedly been caused by hydraulic fracturing activities, as documented by Earthjustice and mapped on their website of "fraccidents" [42]. The Department of Environmental Protection (DEP) issued a proposal in 2010 to rewrite regulations for drilling operations across the state. After months of talks with various stakeholder groups, the state legislature adopted the Horizontal Well Act in 2011 [43]. While the act delineates requirements that should help protect the environment, a number of provisions limit this protection [44]. For example, the act sets forth exceptions so that vertical and permitted wells escape further regulation [44]. Wells disturbing less than three acres or using less than 200,000 gallons of water in a 30-day period are not subject to the requirements of the act [43]. Turning to local regulations, the act specifically provides that the secretary of the West Virginia Department of Environmental Protection "has sole and exclusive authority to regulate" activities related to hydraulic fracturing so that municipal governments cannot interfere with drilling [43]. Furthermore, the secretary has "broad authority to waive certain minimum requirements" if deemed appropriate [43].

\section{Policy Alternatives}

The absence of comprehensive controls and differences of regulatory approaches to horizontal drilling employing hydraulic fracturing between states do not provide adequate protection of local and regional water resources. The legal battles and state legislative revisions in the Marcellus shale region indicate significant public concern about the safety of horizontal well drilling. With the introduction of many fractures along a horizontal wellbore, there are new risks to be considered [45]. Furthermore, these fracturing activities pose risks to river systems and water quality that do not recognize manmade state and municipal boundaries. An individual state is unable to preclude pollutants from upstream states so that multistate or federal controls become important for the maximization of social, environmental, economic, and democratic outcomes for the Marcellus shale region [46]. In a similar manner, a local government may not be in a position to maximize outcomes for a region. Rather, by directing its focus on a small geographic area, a municipality may overlook broader, regional concerns.

The analysis of federal, regional and state regulatory controls over horizontal drilling identify two options for reducing risks accompanying hydraulic fracturing. The first option involves deleting the oil and gas production exemption set forth by the Energy Act of 2005 and requiring disclosure of hazardous chemicals employed in hydraulic fracturing. By deleting the exemption for oil and gas exploration and production, provisions of the Safe Drinking Water Act would offer additional oversight to fracturing activities involving chemicals being injected into the ground. In addition, requiring mandatory reporting of chemicals used in hydraulic fracturing would allow first responders to blowout accidents and other mishaps to have sufficient information for selecting appropriate responses. States often lack adequate controls [47] and because the Marcellus shale formation spans multiple rivers and covers multiple states, a collective, standardized legal framework is needed to ensure equitable protection of the environment and to protect the economic interests of all parties involved. 
In 2011, the Fracturing Responsibility and Awareness of Chemicals Act, which would repeal exemptions for hydraulic fracturing, was introduced in both houses of Congress [48]. However, the act remains in committees and, given the concern over rising energy prices, an initiative to restrict domestic energy production is an unpopular position for policy makers [49]. Moreover, the proposed FRAC Act does not require the public chemical disclosure requirements for fracturing fluids. Thus, the act fails to help identify sources of contamination that may occur from accidental releases and spills. States can enact requirements on the disclosure of chemicals, but most have chosen to include a provision for trade secret protection [50].

A second option to mitigate risks of water contamination by hydraulic fracturing is to strengthen safety controls for the disposal of flowback fluids. For drilling, damages from blowouts are a concern that can be addressed through better well construction standards and adequate construction monitoring and inspection [51]. For probabilistic events including unplanned accidents, the use of environmental impact assessments may reduce negative impacts [15] as well as inspections [52]. Moreover, since hydraulic fracturing in the Marcellus shale region leads to increased concentrations of $\mathrm{Ra}^{226}$, $\mathrm{Ra}^{228}$, and $\mathrm{Ba}$ in flowback waters from Marcellus wells [53], more definitive and demanding treatment specifications for fracturing fluids discharged to publically owned treatment works may be needed to allay concerns that downstream water users are being harmed.

\section{Conclusions}

In the absence of consistent federal standards, individual states, driven by their short-term interests, are allowing actions that lead to long-term damage to common resources. This allows firms to avoid costs reflected in the negative externalities of production. With respect to horizontal drilling, a state's interest is economic gain through liberal gas production without full consideration of regional river basins and ground water supplies [54]. The examination of legal structures regulating hydraulic fracturing provides numerous examples of negative impacts on water quality as a result of poor management of drilling activities. To strengthen the protection of water sources in the Marcellus shale region, federal regulatory exemptions for oil and gas exploration should be deleted and additional resources should be allocated to the management of environmental risks accompanying hydraulic fracturing.

In a similar manner, local governmental actions addressing horizontal drilling may not be optimal. Tension exists between state and local governments over the regulation of hydraulic fracturing because local prohibitions on drilling can thwart state objectives. While the historic delegation of duties and responsibilities to municipal governments enable these governments to take actions on matters of local concern, state legislatures are having second thoughts about whether horizontal fracturing activities are local. Given changes in technology, communications, and transportation, issues relegated to local governments over past centuries may no longer be local. Interconnections of jobs, commerce, and social structures among local governments create externalities that cannot be meaningfully addressed by an individual municipality. Local governments may constitute archaic divisions that create impediments to the well-being of people and the economy of a state. Thus, in exercising their sovereignty, state legislatures are acting to preclude local decisions regarding fracturing that interfere with overriding state objectives. 


\section{References}

1. US Environmental Protection Agency. Plan to Study the Potential Impacts of Hydraulic Fracturing on Drinking Water Resources; EPA/600/R-11/122/November; US Environmental Protection Agency: Washington, DC, USA, 2011.

2. Weinhold, B. The future of fracking. Environ. Health Perspect. 2012, 120, A272-A279.

3. Finkel, M.L.; Law, A. The rush to drill for natural gas: A public health cautionary tale. Am. J. Public Health 2011, 101, 784-785.

4. Furlow, J.D.; Hays, J.R., Jr. Disclosure with protection of trade secrets comes to the hydraulic fracturing revolution. Tex. Oil Gas Energy Law 2011, 7, 289-355.

5. US Energy Information Administration. Short-Term Energy Outlook, Table 5b: U.S. Regional Natural Gas Prices; US Energy Information Administration: Washington, DC, USA, 2012. Available online: http://www.eia.gov/forecasts/steo/tables/?tableNumber=16\#mstartcode=2007 (accessed on 25 September 2012).

6. Rahm, B.G.; Riha, S.J. Toward strategic management of shale gas development: Regional, collective impacts on water resources. Environ. Sci. Policy 2012, 17, 12-23.

7. Wiseman, H. Risk and Response in Fracturing Policy. University of Colorado Law Review, 2013, in press; FSU College of Law, Public Law Research Paper No. 594. Available online: http://ssrn.com/abstract=2017104 (accessed on 22 November 2012).

8. Wiseman, H. State Enforcement of Shale Gas Regulations, Including Hydraulic Fracturing. Energy Institute, University of Texas White Paper, 25 August 2011; FSU College of Law, Public Law Research Paper No. 581. Available online: http://ssrn.com/abstract=1992064 (assessed on 15 November 2012).

9. DiCosmo, B. Jackson Downplays Concerns Over Broad EPA Oversight of Fracking Wells; Clean Energy Report; US Environmental Protection Agency: Washington, DC, USA, 2012.

10. US EPA. Summary of the Clean Water Act. US Environmental Protection Agency: Washington, DC, USA, 1972. Available online: http://www.epa.gov/lawsregs/laws/cwa.html (accessed 25 September 2012).

11. Navigation and Navigable Waters. United States Code, Sections 1311 and 1362, Title 33, Supplement 5, 2006.

12. Technology-Based Treatment Requirements in Permits. US Code of Federal Regulations, Section 125.3, Title 40, 2011.

13. Obold, J. Leading by example: The Fracturing Responsibility and Awareness of Chemicals Act of 2011 as a catalyst for international drilling reform. Colo. J. Int. Environ. Law Policy 2012, 23, 473-500.

14. Regulations for State Programs. United States Code, Section 300H, Title 42, Supplement 4, 2006.

15. US EPA. Summary of the Resource Conservation and Recovery Act; US Environmental Protection Agency: Washington, DC, USA, 2012. Available online: http:/www.epa.gov/lawsregs/ laws/rcra.html (accessed on 25 September 2012). 
16. US EPA. Exemption of Oil and Gas Exploration and Production Wastes from Federal Hazardous Waste Regulations; EPA530-K-01-004; US Environmental Protection Agency: Washington, DC, USA, 2002. Available online: http://www.epa.gov/osw/nonhaz/industrial/special/oil/oil-gas.pdf (accessed on 25 September 2012).

17. Wiseman, H. Trade secrets, disclosure, and dissent in a fracturing energy revolution. Columbia Law Rev. Sidebar 2011, 111, 1-13.

18. Comprehensive Environmental Response, Compensation, and Liability. United States Code, Sections 9601-9675, Title 42, Supplement 4, 2006.

19. Energy Policy Act of 2005. Public Law 109-58, Section 106, 2005.

20. McKay, L.K.; Johnson, R.H.; Salita, L.A. Science and the reasonable development of Marcellus shale natural gas resources in Pennsylvania and New York. Energy Law J. 2011, 32, 125-143.

21. Delaware River Basin Commission Home Page. Available online: http://www.state.nj.us/drbc/ (accessed on 25 September 2012).

22. Delaware River Basin Commission. Draft Natural Gas Development Regulations; Delaware River Basin Commission: West Trenton, NJ, USA, 2011. Available online: http://www.nj.gov/drbc/ programs/natural/draft-regulations.html (accessed on 25 September 2012).

23. Susquehanna River Basin Commission. SRBC met March 15: Reconsidered 22 and approved 20 additional projects; Denied 3 applications; Released proposed low flow policy for public comment. Available online: http://www.srbc.net/newsroom/NewsRelease.aspx?NewsReleaseID=81 (accessed on 25 September 2012).

24. US Environmental Protection Agency. EPA Announces Schedule to Develop Natural Gas Wastewater Standards/Announcement is part of administration's priority to ensure natural gas development continues safely and responsibly. Available online http://yosemite.epa.gov/opa/admpress.nsf/ d0cf6618525a9efb85257359003fb69d/91e7fadb4b114c4a8525792f00542001!OpenDocument (assessed on 2 November 2012).

25. Applebome, P. Drilling Critics Face a Divide over the Goal of Their Fight. New York Times, 10 January 2012, p. A17.

26. Governor's Office, New York. Executive Order No. 41: Requiring further environmental review. Available online http://www.governor.ny.gov/archive/paterson/press/121110PatersonExecutiveOHydraulicFracturing.html (assessed on 2 November 2012).

27. Nolon, J.R.; Polidoro, V. Hydrofracting: Disturbances both geological and political: Who decides? Urban Lawyer 2011, 44, 507-532.

28. Mergen, A.C.; Aagaard, T.; Baillie, J.; Bender, P.; Beauduy, T.W.; Engelder, T.; Perry, S.; Ubinger, J.W., Jr.; Wiseman, H. "Shale" we drill? The legal and environmental impacts of extracting natural gas from Marcellus shale. Villanova Environ. Law J. 2011, 22, 189-224.

29. Calfee, C.; Weissman, E. Permission to transition: Zoning and the transition movement. Plan. Environ. Law 2012, 64, 3-10.

30. Anschutz Exploration Corporation v. Town of Dryden. 940 N.Y.S.2d 458. Supreme Court of New York, Tompkins County, 21 February 2012. 
31. New York State Department of Environmental Conservation. SPDES General Permit for Stormwater Discharges from High Volume Hydraulic Fracturing Operations, Permit No. GP-0-XX-XXX, Fact Sheet; New York State Department of Environmental Conservation: Albany, NY, USA, 2011. Available online: http://www.dec.ny.gov/docs/water_pdf/hvhfgpfactsht.pdf (accessed on 27 September 2012).

32. New York State Department of Environmental Conservation. Proposed express terms 6 NYCRR parts 750.1 and 750.3. Available online: http://www.dec.ny.gov/regulations/77383.html (accessed on 27 September 2012).

33. Ohio Department of Natural Resources. Catalog and maps of Ohio earthquakes. Available online: http://www.dnr.state.oh.us/geosurvey/html/eqcatlog/tabid/8302/Default.aspx (accessed on 26 September 2012).

34. Raleigh C.B.; Healy J.H.; Bredehoeft J.D. An experiment in earthquake control at Rangley, Colorado. Science 1976, 191, 1230-1242.

35. Division of Mineral Resources Management - Oil and Gas. Ohio Administrative Code, Chapter 1501:9, 2011.

36. Ohio Department of Natural Resources. Preliminary Report on the Northstar 1 Class II Injection Well and the Seismic Events in the Youghstown, Ohio Area; Ohio Department of Natural Resources: Columbus, OH, USA, March 2012. Available online: http://ohiodnr.com/downloads/northstar/ UICreport.pdf (accessed 25 September 2012).

37. Pennsylvania Department of Environmental Protection. Act 13 of 2012. Available online: www.portal.state.pa.us/portal/server.pt/community/act_13/20789 (accessed on 25 September 2012).

38. Uniformity of Local Ordinances. Pennsylvania Consolidated Statutes, Section 3304, Title 58, 2012.

39. Robinson Township v. Commonwealth of Pennsylvania, 52 A.3d 463. Commonwealth Court of Pennsylvania, 26 July 2012.

40. Miller, T.; Kauffman, M.K. Is It a Deep Well or a Shallow Well and Who Cares? Energy \& Mineral Law Institute: Lexington, Kentucky, USA, 2010; Chapter 12, Volume 31, pp. 404-431.

41. Exclusivity of Regulation and Enforcement. Code of Virginia, Section 45.1-361.5, Title 45.1, 2012.

42. Earthjustice. West Virginia and fracking. Available online: http://earthjustice.org/features/campaigns/ west-virginia-and-fracking (accessed on 25 September 2012).

43. Legislative Findings; Declaration of Public Policy. West Virginia Code, Section 22-61-2, Chapter $22,2012$.

44. Garvin, D.S.; Coordinator, L. Jr.; WV Environmental Coalition. Legislature Passes Weak Marcellus Shale Bill in Special Session; Sierra Club: San Francisco, CA, USA, 2012. Available online: http://westvirginia.sierraclub.org/newsletter/archives/2012/03/a_001.html (accessed on 26 September 2012).

45. He, H.; Dou, L.; Fan, J.; Du, T.; Sun, X. Deep-hole directional fracturing of thick hard roof for rockburst prevention. Tunn. Undergr. Space Technol. 2012, 32, 34-43.

46. Vogel, E. Parceling out the watershed: The recurring consequences of organizing Columbia River Management within a basin-based territory. Water Alternat. 2012, 5, 161-190. 
47. Wiseman, H.; Gradijan, F. Regulation of Shale Gas Development, Including Hydraulic Fracturing. Energy Institute, The University of Texas at Austin; 31 October 2011. University of Tulsa Legal Studies Research Paper No. 2011-11. Available online: http://papers.ssrn.com/ sol3/papers.cfm?abstract_id=1953547 (assessed 15 November 2012).

48. US House of Representations Bill No. 1084, Fracturing Responsibility and Awareness of Chemicals Act of 2011. Available online: http://www.govtrack.us/congress/bills/112/hr1084 (accessed 27 September 2012).

49. Bittle, S.; Rochkind, J.; Bosk, J. Confidence in U.S. Foreign Policy Index: Energy, Economy New Focal Points for Anxiety over U.S. Foreign Policy. Public Agenda: New York, NY, USA, 2008. Available online: http://www.publicagenda.org/files/pdf/foreign_policy_index_spring08.pdf (accessed on 25 September 2012).

50. Murrill, B.J.; Vann, A. Hydraulic Fracturing: Chemical Disclosure Requirements; CRS Report for Congress; Congressional Research Service: Washington, DC, USA, 2012.

51. Zhang, J. Pore pressure prediction from well logs: Methods, modifications, and new approaches. Earth. Sci. Rev. 2011, 108, 50-63.

52. Wiseman, H. Fracturing legislation applied. Duke Environ. Law Policy Forum 2012, 22, 361-384.

53. Haluszczak, L.O.; Rose, A.W.; Kump, L.R. Geochemical evaluation of flowback brine from Marcellus gas wells in Pennsylvania, USA. Appl. Geochem. 2012, in press.

54. Powers, E.C. Fracking and federalism: Support for an adaptive approach that avoids the tragedy of the regulatory commons. J. Law Policy 2011, 19, 913-971.

(C) 2012 by the authors; licensee MDPI, Basel, Switzerland. This article is an open access article distributed under the terms and conditions of the Creative Commons Attribution license (http://creativecommons.org/licenses/by/3.0/). 